\title{
Engaging Practitioners as Inquirers: Co-constructing Visions for Music Teacher Education in Nepal
}

\author{
Danielle Shannon Treacy
}

\begin{abstract}
This chapter explores how co-constructing visions might engage teachers as inquirers in a 'majority world' context by reflecting on a series of 16 Appreciative Inquiry workshops involving over 50 musician-teachers in the Kathmandu Valley, Nepal in 2016. It extends the concept of teachers' visions (Hammerness, Teach Educ Q 31(Fall):33-43, 2004) through socio-cultural anthropologist Arjun Appadurai's notions of the imagination (Modernity at large: Cultural dimensions of globalization. University of Minnesota Press, Minneapolis, 1996) and the social and cultural capacity to aspire (Culture and public action. Stanford University Press, Stanford, 2004). The chapter reflects on the processes that took place when co-constructing visions, including the ways co-constructing visions may have been the fuel for action, and analyzes the implications of the resulting co-constructed visions. The findings highlight the importance of developing and supporting collaborative learning for the development of both preservice and inservice music teacher education.
\end{abstract}

Keywords Teachers' visions · Co-constructed visions · Imagination · Capacity to aspire $\cdot$ Appreciative inquiry $\cdot$ Majority world $\cdot$ Nepal

Music teacher education today is faced with the challenge of preparing professionals for an uncertain future; teachers who are capable of ethically engaging in intercultural settings, and continuously and systematically inquiring to increase their professional knowledge (see e.g. Cochran-Smith and Lytle 2009; Holgersen and Burnard 2013). One possible way of engaging with such an uncertain future is through envisioning. In the field of education, Karen Hammerness defines teachers' visions as the images that teachers hold of "ideal classroom practices" and that reveal their "hopes and dreams" $(2004,34)$. She describes how visions represent a teacher's aspirations, a reach beyond their current practice, and she connects them

D. S. Treacy $(\square)$

Sibelius Academy, University of the Arts Helsinki, Helsinki, Finland

e-mail: danielle.treacy@uniarts.fi

H. Westerlund et al. (eds.), Visions for Intercultural Music Teacher Education, Landscapes: the Arts, Aesthetics, and Education 26,

https://doi.org/10.1007/978-3-030-21029-8_13 
to teacher motivation both to change teaching practice and curriculum, and in relation to teacher identity and feelings of success (Hammerness 2015). Visions have also been found to have implications for teacher education. It has been proposed, for example, that effective teacher education programs are designed around and promote a clear and shared vision of good teaching, are coherent, and offer opportunities to learn that are aligned with the vision and grounded in teaching practice (Darling-Hammond 2006; Hammerness 2013; Klette and Hammerness 2016). Furthermore, the relationship between a teacher's vision and the teacher education program vision has been found to either help or hinder new teachers' development (Hammerness 2015).

In music teacher education, visions have been recognized as a possible tool "for critical examination of music teaching traditions and beliefs that so often (unconsciously) shape ideas and practices" and for "assessing music teaching and learning" (Ferm Thorgersen et al. 2016, 60). Similarly, Talbot and Mantie describe the "truly reflective practice required for visioning" $(2015,176)$ which they highlight as an important way of questioning and resisting a "passive acceptance of the legitimate order" $(2015,177)$ in the music teaching profession. Talbot and Mantie stress that "the failure to analyze and imagine how things could be different, however - to imagine different rationalities - almost certainly guarantees that things will not change" $(2015,176)$. This said, Conkling has recognized the complex and interrelated influences of both compliance and utopian thinking on teachers' visions. She uses examples of the myths of prediction and control, teacher as expert, and the ability to teach as a natural talent, to illustrate that "compliance is a powerful force in shaping teachers' visions" $(2015,191)$ and therefore "might be difficult for preservice teachers to avoid" $(2015,191)$. Thus, she argues that music teacher educators have a responsibility to preservice teachers to acknowledge the policies and practices that may constrain them as future music teachers, while designing meaningful and transformative experiences and teaching "envisioning greater equity, inclusion, creativity, and joy for the children who will be in our preservice teachers' future classrooms" (Conkling 2015, 191).

These understandings of teachers' visions may be insufficient, however, in a research study that involves co-constructing visions for the development of music teacher education in Nepal. First, because visions have been found to be individual and not necessarily shared by all colleagues, other educators, or other institutions (Ferm Thorgersen et al. 2016; Hammerness 2013; Juntunen 2014). Second, because the research on teacher visions and program visions has so far been limited to western contexts and countries with established teacher education programs. In a 'majority world' ${ }^{1}$ context, such as Nepal, where music teacher education is only beginning to be developed, the situation may be radically different.

Due to these limitations, this chapter extends the concept of teachers' visions through the case of music teacher education in Nepal and socio-cultural

\footnotetext{
${ }^{1}$ The 'majority world' is a concept offered by Dasen and Akkari (2008) to challenge western ethnocentrism and to acknowledge that, in terms of global population, the rich, industrialized nations of the West and North actually comprise the minority.
} 
anthropologist Arjun Appadurai's notions of the imagination (1996) and the social and cultural capacity to aspire (2004). Although a music education curriculum was adopted by the Nepalese Ministry of Education in 2010, there is currently no formal, government-recognized music teacher education. Consequently, the Nepal Music Center (NMC) $)^{2}$ contacted the Sibelius Academy, University of the Arts Helsinki in 2012, which led to collaborative developmental work and research on music teacher education between the two institutions. As its name suggests, the resulting research project, Global Visions Through Mobilizing Networks: Co-Developing Intercultural Music Teacher Education in Finland, Israel and Nepal, has an overall objective to explore the negotiation of visions for co-developing intercultural music teacher education globally through partnerships and collaboration. As Nepal is a country characterized by extraordinary diversity, currently recognizing 126 caste/ethnic groups, 123 languages spoken as mother tongue and ten religions (Government of Nepal 2012), and as it is experiencing an intensified rate of societal change and globalization, the development of intercultural music teacher education in Nepal may be seen to play an important role in positioning diversity and difference as opportunities, rather than problems to be overcome.

In the absence of music teacher education, musicians in the Kathmandu Valley are employed to teach music in private schools, music institutions, and private homes, usually on the basis of artistic merit; thus, I use the term musician-teachers. As part of the Global Visions project, I facilitated a series of Appreciative Inquiry ${ }^{3}$ workshops with musician-teachers to co-construct visions for music education in Nepal over an 11-week period between April and June 2016. The workshops were conceived as one possible way to address some of the aims of the Global Visions project, including promoting music teacher agency, creating a network of practitioners, and having a practical impact on the development of music teacher education by including practitioners in the process of knowledge building.

My work in the Global Visions project begins with a presupposition of equality (Ranciere 1991), as I aim to adopt an anti-colonial stance (Patel 2014) in order to ethically undertake a research project immersed in the complexities of western ethnocentrism (e.g. Dasen and Akkari 2008). I am a first-generation Canadian (Canada being a settler colony), of parents who emigrated from both colonized and colonizing European countries, and I now live in Finland as an immigrant. In Nepal, my whiteness and university-researcher status carry privilege and power, positioning me as a 'foreign expert.' I am simultaneously answerable to the Nepali participants, to the research project leaders, and to the Sibelius Academy and Academy of Finland who fund my work. My personal investment in this research project is linked to the successful completion of my doctoral studies and to my future career, which made me dependent upon Nepali musician-teachers attending and participating in the

\footnotetext{
${ }^{2}$ The Nepal Music Center (NMC) was established in 2005 and is home to "Nepal Sangeet Vidhyalaya" (NSV) the first music school in Nepal established with due permission from the Ministry of Education, Government of Nepal. Representatives from NMC were included in the national panel that collaborated with the Ministry of Education to develop the national music curricula.

${ }^{3}$ For more on Appreciative Inquiry (AI), see e.g. Cooperrider, Whitney and Stavros (2005) and Watkins, Mohr and Kelly (2011); the workshops will be described in detail below.
} 
workshops, not only for the co-construction of knowledge but also for my own professional gain (Patel 2014).

Although a primary aim of the workshops was to co-construct visions for music education in Nepal, I was conscious of the limited availability of professional development opportunities or active music teacher associations in Nepal. Consequently, I envisioned the workshops as a community of inquirers in which participants could develop their teaching through learning from and with each other, and that this community might support the building of a music teacher network and thus have value beyond its research beginnings. As such, this chapter addresses the following research question and sub-questions:

- How might the process of co-constructing visions engage practitioners as inquirers in a majority world context?

- What are the characteristics of the processes that take place when coconstructing visions?

- In what ways might co-constructing visions be the fuel for action in a majority world context?

\section{Imagination and the Capacity to Aspire}

To push towards an understanding of co-constructed visions, and move beyond the sphere of North America and Europe, I draw upon the work of Arjun Appadurai, particularly his notions of the imagination (1996) and the social and cultural capacity to aspire (2004). Appadurai identifies the imagination, especially when collective, as a potential "fuel for action" $(1996,7)$ and thus "central to all forms of agency" (1996, 31). He describes it as,

An organized field of social practices, a form of work (in the sense of both labor and culturally organized practice), and a form of negotiation between sites of agency (individuals) and globally defined fields of possibility. (Appadurai 2006, 31)

The imagination informs the daily lives of ordinary people in numerous ways. It is used both to discipline and control citizens, and for collective dissent and redesigning ways of being together (Appadurai 2000).

Appadurai's ideas of imagination flow into what he describes as the capacity to aspire, "the social and cultural capacity to plan, hope, desire, and achieve socially valuable goals" (Appadurai 2006, 176). He describes aspirations as being related to "wants, preferences, choices, and calculations" (Appadurai 2004, 67) and being formed through social interaction and located "in a larger map of local ideas and beliefs" $(2004,68)$. As such, co-constructing visions with Nepali musician-teachers could be understood as engaging their collective imagination in aspiring towards what they deem to be socially valuable goals.

According to Appadurai (2004), however, the capacity to aspire is unevenly distributed in society. As a navigational capacity, it is the better off or more privileged in any society who "have used the map of its norms to explore the future more frequently and more realistically, and to share this knowledge with one another more 
routinely than their poorer and weaker neighbors" (Appadurai 2004, 69). This uneven distribution may also be linked to opportunities to practice the capacity to aspire, for instance in educational development globally where practitioner expertise and participation is often overlooked. This has also been the case with the Nepali musician-teachers who have so far not been included by the government in the planning of music teacher education. Appadurai (2006) argues that the uneven distribution of the capacity to aspire is both a sign and gauge of poverty, but something that can be changed by politics and policy.

Intimately connected to the capacity to aspire is what Appadurai (2006) calls the right to research, which he defines as the capacity to systematically increase one's current knowledge relative to a task, goal, or aspiration (176). The capacity to aspire and the right to research are intimately connected because "without aspiration, there is no pressure to know more. And without systematic tools for gaining relevant new knowledge, aspiration degenerates into fantasy or despair" (Appadurai 2006, 176177). Appadurai further argues that the right to research is essential to "claims for democratic citizenship" $(2006,167)$, as one needs to be informed in order to participate in democratic society especially in a world of rapid change and global flows (2006, 177). Hence, aspiring together may also motivate Nepali musician-teachers to learn both from and with each other and towards increased democratic participation.

\section{Co-constructing Visions for Music Education in Nepal}

In order to address the first research sub-question, I here introduce Appreciative Inquiry and provide a detailed description of how the visions were co-constructed.

\subsection{Appreciative Inquiry}

An early challenge in this study was to find a method of co-constructing visions for music education in Nepal that would avoid ethnocentrism and coloniality. I chose to apply Appreciative Inquiry (AI, see e.g. Cooperrider et al. 2005; Watkins et al. 2011), which comes from the field of organization development and the practice of change management, and is grounded in social constructionist theory (e.g. Gergen 1978, 2009). AI appeared to be particularly well suited to this study, as envisioning together is built into the four phases of its 4D cycle of Discover, Dream, Design and Destiny. Reminiscent of Appadurai's notion of imagination, AI strongly connects envisioning to action, as Cooperrider and Whitney explain that "human systems are forever projecting ahead of themselves a horizon of expectation (...) that brings the future powerfully into the present as a mobilizing agent" $(2001,624)$. Although the participants were musician-teachers, the workshops were predominantly discussion-based. While we did make music together at the beginning of most workshops, it was the discussion, not the music-making, that aimed specifically at co-constructing visions. 
Throughout the inquiry, I applied AI critically, remembering that it was developed in the United States of America and that most of the references that informed my workshop planning were North American (e.g. Cooperrider et al. 2005; Watkins et al. 2011). AI, however, is not new to Nepal (see e.g. Messerschmidt 2008; Odell and Mohr 2008). It has been used since 1994 (NAINN n.d.), including Imagine Nepal (IN), which was launched in 2002. According to the Imagine Nepal website

\section{AI practitioners in Nepal incepted IN to contribute to restore peace and harmony in Nepal by using their talent and skills in managing conflicts and fostering equitable development through the process of Appreciative Inquiry.... as a movement for peace and prosperity in Nepal. (Imagine Nepal, About Us, par. 2)}

Cooperrider and colleagues describe this as having involved the mobilization of "more than 1,000 appreciative leaders throughout Nepal" (Cooperrider et al. 2005, vii).

In addition to an awareness of possible ethnocentrism, applying AI critically also meant that I was engaged in ongoing ethical deliberations related to issues of power, cross-cultural (Liamputtong 2010) and anticolonial (Patel 2014) research, and informed by a reach for collaborative ethnography (Lassiter 2005) and ongoing dialogue with my Nepali co-facilitator. In addition, prior to facilitating these workshops in 2016, I visited the Kathmandu Valley on two different occasions for 3 weeks each in 2014. The music lessons I observed during school visits, interviews with seven musician-teachers and seven administrators from six different schools, and two pilot AI workshops in a music institution during 2014 served to inform the planning of the 2016 workshops, both in terms of the questions asked as well as ethical, methodological and practical considerations. For example, although the Global Visions project aims to envision music teacher education, these workshops focused on music education in general with a goal of producing knowledge for the development of Nepali music teacher education. This focus was a result of my interviews with musician-teachers in 2014 because when I asked questions related to their wishes for music teacher education the responses were rather limited. In 2016, while planning and facilitating the workshops I continued to visit schools and music lessons, this time also sometimes teaching.

\subsection{Building a Network}

In the planning stages, the workshops were targeted to musician-teachers teaching in Kathmandu Valley's private schools as many of these schools offer music as an extracurricular activity or school subject. As an outsider, it seemed to make sense to focus on school-based musician-teachers if music was a new subject in the national curriculum, and the Nepal Music Center did not have any knowledge of musicianteachers in government schools. However, I came to learn that many musicianteachers teach in combinations of private schools, music institutions, and homes. Additionally, if a major aim of the study was to build a network of music teachers then limiting participation to certain teachers would begin the network from a 
position of exclusion rather than inclusion. Thus, I chose to open participation to all musician-teachers.

Invitations were sent via telephone, email and Facebook to the musician-teachers who had participated in the pilot workshops I offered in 2014, administrators from schools I had visited in 2014, and teachers from the Nepal Music Center's network and one other music institution's network. Those invited directly were informed that they could invite others. The workshops took place with three different groups of musician-teachers. For clarity and anonymity, they are here named Group A and B, which took place in two different music institutions, and Group C, which took place at a private school. Group C's workshops began the same week as Group B's with the goal of bringing them together, thus the same materials were used in both. In addition, a separate workshop titled, Encouraging girls' participation in music in Nepal, was organized as gender issues, namely the increased challenges females face in studying music or pursuing a career in music, arose as an important topic during the other workshops, and I wanted to provide a female-only space for discussion. For the sake of brevity, this workshop is presented elsewhere (Treacy 2019).

Participation in the workshops and the study as a whole was voluntary and informed consent was given by all participants. The first workshops were bilingual, with all written materials in both English and Nepali, and an effort to ensure that all speech was translated between English and Nepali. As the participating musicianteachers were comfortable participating in English, however, workshop materials from the second workshops onward were only in English. A translator continued to be present at all times and participants were encouraged to express themselves both verbally and in written responses using the language of their choice. While acknowledging that "backstories are as limited as all the data excerpts that appear" (Jackson and Mazzei 2012, xii), I offer Table 1 as a brief introduction to the musician-teachers to provide context for the reader.

\subsection{Co-constructing with Nepali Musician-Teachers}

For the purposes of this chapter, the empirical material can be divided into three types. First are the audio recordings from all 16 workshops, transcribed in part and translated as needed. Second are participant written responses, both individual and group. Third are the handouts that I created for the workshops, the notes that I took during the workshops, my personal researcher diary, and what I have called a dialogic researcher diary. In September 2016, with the musician-teacher who acted as the co-facilitator and translator for the workshops, I initiated this dialogic researcher diary, in which we took turns writing and responding to each other's reflections, as a space for ongoing dialogue.

Throughout the process, meaning developed "within relations" (Kuntz 2015, 69). Following each workshop, I used the written response sheets completed by the participants and my own notes from the workshops, combined with carefully listening to the recordings, to compile and thematize the participants' responses and create a plan and handouts for the following workshop. An effort was made to preserve 
Table 1 Overview of the musician-teachers involved in the workshops

\begin{tabular}{|c|c|}
\hline \multirow{4}{*}{$\begin{array}{l}\text { Number of } \\
\text { participants }^{\mathrm{a}}\end{array}$} & 53 musician-teachers participated in at least one of the workshops: \\
\hline & Group A total 16, each workshop 3-9 \\
\hline & Group B total 29, each workshop 16-23, including 2 non-Nepali \\
\hline & Group C total 8, each workshop 5-7 \\
\hline \multirow[t]{3}{*}{$\begin{array}{l}\text { Number of } \\
\text { workshops }\end{array}$} & $\begin{array}{l}\text { Group A: } 83 \text {-h workshops (the first two of which were repeated with } \\
\text { different groups of teachers for a total of ten meetings }{ }^{b} \text { ) }\end{array}$ \\
\hline & Group B: 4 2-h workshops \\
\hline & Group C: 2 workshops ranging from 1 to $1.5 \mathrm{~h}$ each \\
\hline \multirow[t]{4}{*}{ Gender } & 9 women: \\
\hline & Group A total 2, 1 participated throughout \\
\hline & Group B total 7, 5 participated throughout \\
\hline & No female musician-teachers worked at Group C's school \\
\hline \multirow[t]{2}{*}{ Where they teach } & Private schools, music institutions, homes \\
\hline & Some teach in as many as five different places \\
\hline Types of lessons & Private, small and large groups, mixed ensembles \\
\hline $\begin{array}{l}\text { Teaching } \\
\text { experience }\end{array}$ & Ranged from a few months to decades \\
\hline \multirow[t]{3}{*}{ How they learned } & Formally: private and group lessons in music institutions and universities \\
\hline & $\begin{array}{l}\text { Informally: self-teaching, learning with or from a friend or family member, } \\
\text { making use of the internet, video lessons and reference books }\end{array}$ \\
\hline & $\begin{array}{l}\text { In India: one in a university brass band, and one had } 5 \text { years of formal music } \\
\text { studies }\end{array}$ \\
\hline
\end{tabular}

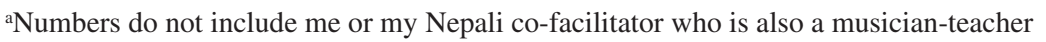

bIn the beginning, Group A workshops were offered on 2 different days of the week as finding a single time that suited many musician-teachers was challenging

the musician-teachers' own words as much as possible. We then began each workshop with dialogic reflection on my interpretations in group discussions, in which I also asked questions to clarify comments or ideas about which I was uncertain, for example, the social stigma regarding music and musicians, the prevalence of creating or composing in music lessons, or the 'right' music to teach in schools. Drafts of this chapter were also shared with workshop participants prior to publication, and the ongoing findings of the project as a whole continue to be regularly shared "so that they may serve and be interrogated by [the] community" (Patel 2014, 369). In the text below, all quotes from the participants appear in their original English.

\subsection{Developing the Capacity to Aspire Through the 4D Cycle}

\subsubsection{Discovering the Potential for Learning from and with Each Other}

The Discovery phase of AI aims to appreciate what the participants deem to be "the best of what is" (Cooperrider et al. 2005, 5). To do so, the musician-teachers began by interviewing a partner, following an interview guide that I had created. One of the core principles underlying $\mathrm{AI}$ is that "the questions we ask set the stage for what 
we "find" (Watkins et al. 2011, 73) and that "even the most innocent question evokes change" (Cooperrider and Whitney 2001, 623). Indeed, Cooperrider and Whitney maintain that "inquiry and change are a simultaneous moment" (Cooperrider and Whitney 2001, 623). Thus, I present the initial questions in Table 2 to allow the reader to reflect upon how they may have shaped the resulting coconstructed visions. The questions were different for the different groups because Group A was based at the same music institution as the 2014 pilot workshops and I wanted to respect the time and discussions of the pilot workshop participants. I did so by using the three themes they had identified as being the most important to pursue as a starting point: Making teaching and learning fun, encouraging students' self-expression, and teaching with limited resources (see Table 2 Group A questions 3, 4 and 5). With Group B and C, however, we started from the very beginning and I adapted the generic Appreciative Inquiry questions (Cooperrider et al. 2005, 25; Watkins et al. 2011, 155-156; see Table 2 Group B and C questions 1, 2 and 7), but also added questions based on my developing understandings from earlier interviews, workshops, and school visits (see Table 2 Group B and C questions 4 and 5). Upon reflection, the number of questions were too many for the time available, however they served their important role of stimulating dialogue and thus discovery with fellow musician-teachers.

Following the partner interviews the musician-teachers formed groups of approximately six teachers to reflect on the interviews by sharing a story or highlight. The small groups were then asked to decide on three to five topics or themes they wished to pursue during the next session. The process of interviewing a peer, listening carefully to their answers, taking notes, and then introducing their partner to a group took some explanation as to why the teachers should not simply write down their own answers. This, however, was the beginning of a process aimed at developing a community for learning from and with each other:

I thought I was the only one who faces problems teaching students but there are other teachers with the same problems and so we can together overcome these problems. (Musician-teacher)

At the same time, it provided an opportunity for the musician-teachers themselves to be inquirers, practice the research skills of interviewing, and impact the direction of our workshops.

My role in the workshops was that of planner and facilitator. As a facilitator, I aimed to be for the participants "a means of knowledge - without transmitting any knowledge" (Rancière 2010, 2), instead highlighting the already existing local expertise as well as the potential for learning from and with each other. This challenged the musician-teachers' expectations for a workshop led by a 'foreign expert.' In the anonymous feedback, for example, 3 of the 18 returned response sheets mentioned the "visiting teacher" or "foreign trainer" "from [an] international university" as part of their motivation for first coming. One of the musician-teachers elaborated:

it was very surprising and some of [the teachers] were confused [about] what is going on in the workshops. Because, you were supposed to talk all the time. They thought that you know all the things and will tell to the others.... This is because also they never had that type of experience and their school also never asked how school can be made better. (Musician-teacher) 
Table 2 Questions used for partner interviews during the first workshops

\section{Group A discovery interview questions}

1. Think about a time when you were really engaged in and excited about your work. Please tell me a story about that time.

2. Think about a time when you learned something that helped make your teaching even better. Please tell me a story about that time.

3. Think about a time when students were really motivated and engaged. Please tell me a story about that time.

4. Think about a time that promoted student self-expression. Please tell me a story about that time.

5. Think about a time when you experienced great music teaching even though there were limited resources available. Please tell me a story about that time.

\section{Group B and C discovery interview questions}

1. Best Experience: Think about a highpoint in your experience as a music teacher. Please share a story about that time. When and where did it occur? What happened? Who was involved? Why do you consider it a high point? What made it exciting or engaging?

2. Values: A value is something you consider to be of worth, excellence, usefulness, or importance; something you regard highly. What do you especially value:

(a) About being a music teacher?

(b) About your strengths as a music teacher?

(c) About the school(s) you teach in?

3. People learn in different ways and experience the joy of learning in a variety of settings, both in and out of the classroom.

(a) Describe a learning or mentoring experience that was particularly meaningful for you. When and where did it occur? Who was involved? Why was this experience so effective and memorable?

(b) In your experience, what are one or two of your most effective tools or techniques for enhancing student learning and success?

4. In your experience, what are the best ways of engaging students when they are at different levels of ability but in the same class or lesson?

5. What have you found to be the most useful resources or approaches for structuring student learning throughout the school year?

6. What do you consider to be the most important factor contributing to excellent music education in your school(s)?

7. Three wishes: What three wishes do you have for enhancing music teaching and learning in Kathmandu?

\subsubsection{Navigating the Capacity to Aspire}

The Dream phase calls for participants to imagine "what might be" (Cooperrider et al. 2005, 5) if the best moments and experiences discovered in the previous phase were to occur more regularly. My uncertainty about how the process would unravel was frequently mentioned in my researcher diary:

I have a hard time imagining how the next session will go. It is an experiment for me too.

(Researcher diary)

In all three groups, we began the second workshop by reviewing the summary of themes that I had compiled and thematized based on the participants' written 
response sheets, my own notes taken during the first workshop, and my listening to the audio recordings. This was followed by a full group discussion of both the themes and my interpretations.

In Group A, the first Dream activity involved a group discussion guided by questions to imagine what outstanding music education, including their own teaching, could be like 3 years from now. This proved challenging, so for the third workshop I approached the dream by building upon a comment from one of the musicianteachers in the previous session, "If we want to change anything then we need to start from ourselves." Again, we tried partner interviews, but this time with five questions related to what they wished to accomplish or what they imagined success would look like for them this academic year. ${ }^{4}$ Based upon these interviews they brainstormed opportunities to improve music teaching and learning in Kathmandu. This brainstorming continued in workshop four when we also experimented with having $10 \mathrm{~min}$ of freewriting to stimulate the discussion.

My ongoing search for different approaches to Dreaming in the workshops with Group A informed my planning of the second workshops with Groups B and C. Group B was asked to form small groups and, from the summary of themes, agree upon three that could have the greatest impact towards excellent music education. For each theme, they were asked to brainstorm an action plan and aspiration statement (ex. By May 2017 what we most aspire to in terms of X is Y). In Group C our workshop started $30 \mathrm{~min}$ late but had to end on time since we met before their music lessons. As a result, we only got as far as each teacher selecting their personal three, and missed the opportunity to then engage in discussion to agree upon a shared three.

For the fifth workshop with Group A, I prepared a handout that combined the summary of themes from Group B and C's first workshops with the themes that had been brainstormed during Group A's third and fourth workshops to stimulate further discussion and reflection for the creation of their own dreams. From this, each teacher selected three themes that they believed could have the greatest impact towards excellent music education, and during the following workshop Group A agreed on three shared themes.

\subsubsection{Design and Destiny}

In the Design phase participants co-construct a future "grounded in the realities of what has worked in the past combined with what new ideas are envisioned for the future" (Cooperrider et al. 2005, 7). In both Group A and Group B, brainstorming around the selected themes led to the formation of the co-constructed visions. In Group A, for each of the three agreed upon themes, the musician-teachers brainstormed the key elements of their ideal version of it and ideas about specific things that could occur now or in the near future for its realization. In Group B, each musician-teacher was asked to first independently select the theme s/he found most

\footnotetext{
${ }^{4}$ The academic year started around April 20, with some variation by school.
} 
compelling to work with and then form a small group with others who selected the same theme. In these small groups they then brainstormed to create a provocative proposition, meaning "a statement that bridges the best of 'what is' and 'what might be" " to convey positive images of the ideal future (Cooperrider et al. 2005, 168), and an action plan. Time was given at the end of this workshop to report back to the larger group to get feedback before refining their ideas and sharing them with me so that I could type them for the final workshop handout. This kind of brainstorming was received quite positively:

For me it was really wonderful to have a brainstorming session on various issues, which I'd never thought of before. (Musician-teacher)

The Destiny phase is about finding "innovative ways to help move the organization closer to the ideal" (Cooperrider et al. 2005, 7). During the final workshop with Group B we read and reflected upon each of the co-constructed visions with a focus on refining them. The musician-teachers were given time after we read the draft of each vision to reflect on and independently write feedback guided by questions provided on the response sheets. This was followed by a full group discussion. The process was repeated for each of the co-constructed visions. Allowing time for written response prior to the group discussion was an attempt to capture plurality and what might remain unsaid. Throughout the AI 4D cycle, I was highly aware that its focus on co-constructing, and thus consensus, resulted in a loss of multiple perspectives. Time restraints, however, influenced both the number of questions for which teachers wrote responses and how much discussion could be had.

With Group A we took the opportunity to have a group discussion based on the drafts of Group B's co-constructed visions as a way of sharing and stimulating ideas, and because the two groups had some overlapping themes. The group discussion was guided by the same questions as Group B. Group A's final workshop then began with reviewing, reflecting upon and refining their own co-constructed visions.

As a final activity in both groups, we created and shared Individual Actions based on the parts of the visions each musician-teacher wanted to bring to life. The Individual Actions were either in the form of a simple commitment (e.g. an action that could easily be taken within the next few weeks), an offer (e.g. sharing a resource or expertise, giving a workshop, helping another teacher, collaborating with someone), or a request (e.g. something needed from another person or group to contribute to one of these dreams) (see Watkins et al. 2011, 241-242). I chose this as a final activity because I noticed that as we became better at imagining an ideal future, the challenge became pinpointing how to realize it. Individual Actions appeared to be a way for each person to find some step that they could take. The result was that we ended the workshops "on an uplifting note" (Researcher diary).

My researcher diary from these last days in Kathmandu reminds me how exhausting and emotional this process was, and how my uncertainties continued until the end. Referring to our penultimate workshop with Group A, I wrote: 
Monday's workshop was nice. Maybe it's because I've been feeling tired that I feel a bit like the momentum is down. Why did [Musician-teacher] stop coming? Did we go beyond our natural life span? Though, when I said that the following Monday would be our last it felt sad to me as well. (Researcher diary)

Having spent so much time together, our final Group A workshop had an unexpected festive feel. In addition to the snacks that I usually provided, the musicianteachers surprised me by bringing special foods to share with the group that they wanted me to try.

\section{The Co-constructed Visions}

To address the second research sub-question, here the co-constructed visions are presented, followed by a focus on how the visions led to both envisioning continued collaboration and action in the form of an all-female gig and a community of musician-teachers.

\subsection{The Visions}

The visions that resulted from the 4D cycle are summarized in Table 3, organized from macro to micro levels. I understand these visions to be "temporally located" (Patel 2014). In another time or with other teachers, the resulting visions may have been different. These visions are also important for what they do not include, or their silences. For example, despite gender issues being highlighted in workshop discussions and even inspiring a female-only workshop, they did not find their way into the visions (Treacy 2019). It is also crucial to contemplate the degree to which my questions and presence influenced the resulting visions. For instance, in retrospect the leading nature of Group B and C's third question, which began with the statement "People learn in different ways and experience the joy of learning in a variety of settings, both in and out of the classroom" (see Table 2), may have led to the seventh vision, "That music teachers would use a variety of teaching and learning techniques in the classroom to make learning easier for students because no one method will work for every teacher or every student" (see Table 3). Finally, these visions should be viewed not as a final product, but as the beginning of a process, and not only for the musician-teachers who co-constructed them. The visions have been shared with decision makers currently involved in the development of Nepal's first government-recognized music teacher education program, for example in March 2017 and November 2018 when I presented my ongoing research project and preliminary findings to representatives from the Ministry of Education, Tribhuvan University, and the Nepal Music Center. 
Table 3 Summary of the co-constructed visions (organized from macro to micro levels)

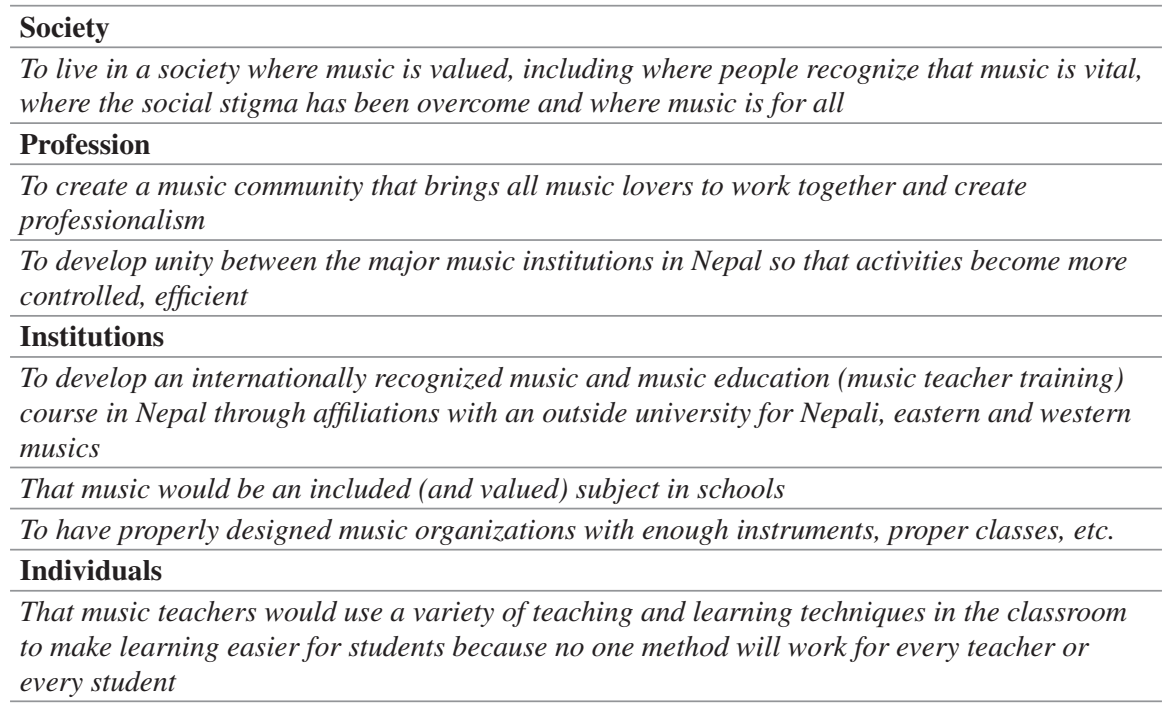

\subsection{Imagining Continued Collaboration}

As can be seen from the co-constructed visions, the experiences in the workshops led to the musician-teachers envisioning continued collaboration. This is reflected in the vision to "Create a music community that brings all music lovers to work together and create professionalism." Although collaborating to reflect on their teaching practice and learn from and with each other was a new experience, musician-teachers overwhelmingly felt that this kind of community building was "necessary." Such a lack of professional collaboration is common not only for Nepali musician-teachers, but music teachers globally who often work in relative isolation (see e.g. Bates 2011; Burnard 2013; Sindberg 2011; Schmidt and Robbins 2011).

This vision was elaborated through discussions and written responses. One group's response captures some of the details:

Build a community so that skills are divided among many and the community becomes the 'voice of the voiceless,' networking is created with other music lovers (teachers, students and aficionados), and lobbying with the government for various things. The community is a bridge between the government and professionalism. The community works as an advocate to the government regarding music education policy; a creator of awareness among parents and students; provides opportunities to students and teachers; regulation/standard maintenance or monitoring is also what a community for music could do. (Group written response to dream activity, parenthesis original)

Through engaging their capacity to aspire, the musician-teachers envisioned the music community exercising voice, for example through "lobbying with the government" and creating "awareness among parents and students." This capacity to 
exercise voice is crucial to inclusion and participation in democracy (Appadurai 2004). Appadurai considers voice to be a cultural capacity,

because for voice to take effect, it must engage social, political, and economic issues in terms of ideologies, doctrines, and norms which are widely shared and credible, even by the rich and powerful. Furthermore, voice must be expressed in terms of actions and performances which have local cultural force. (2004, 66-67)

In the case of the imagined music community, musician-teachers recognized context-specific challenges. One of the groups raised a concern:

even if a community is formed, there will be fractures or factions based on nepotism, favouritism, difference in customs or ethnicity, or religion, or groupism (these are all the ill effects of politics and its infection on professionalism and community). (Group written response to design brainstorming, parenthesis original)

There was general consensus that "this prevails in our society" and "that's how it has always been." In imagining how it might be avoided, the majority of ideas were connected to appreciating and learning through difference,

difference in community and ideas should be used to enhance education instead of making it an issue for ex. instrument, ideas, ethnic music. (Musician-teacher)

Appreciating difference involved getting to know others from different backgrounds for example through shared activities like workshops, and accepting and learning "all forms of music":

This can be avoided when learning music from other cultures/ethnicities is encouraged (sarangi and sanai are instruments played by 'low caste people', but if a movement starts where people accept folk instruments/music regardless of 'social stigma' then it's a positive change). (Musician-teacher, parenthesis original)

At the same time, however, in this context it appears that not all differences are welcome, as ideas including keeping the community "free of politics" and even excluding "politically affiliated people" were offered, echoing the group response above. A musician-teacher explained:

we were talking about creating an open community where we can include everyone from society because this is the only way of creating sustainable social development.... In this context, teachers fear that if they allowed any political party in the community then they would certainly... use [it] for political purpose. Politicians are always concerned with their party agenda not the teacher's benefit. It is good to have politicians so that they can help us raise the music teacher's agenda to national policy makers. But, they only do so if they are getting power and position. (Musician-teacher)

Teachers also stressed ideas related to providing equal opportunities in a society that is very stratified along ethnic and caste lines. Musician-teachers envisioned a music community in which "each person should be valued equally, treated equally and for example if we favour someone then there should be a specific reason" (Musicianteacher). It was also recognized how these attitudes need to start from within:

Unless music teachers, music learners, and music researchers view one another with equal respect, we cannot expect the society to view music positively as a whole \& community building isn't possible. (Musician-teacher) 


\subsection{Fuel for Action}

Although we ended the workshops by sharing Individual Actions, my intention was never to follow up on these. Rather, I saw them as an opportunity for the teachers to envision small ways that they could create change. This was particularly important, because as it became easier to envision what the future could look like for music education in Nepal, it continued to be challenging to envision how and who could help the visions be realized. Feelings of agency, however, were evident in the musician-teachers' final responses, for example, to the question about what they had valued about participating in the workshops one teacher wrote:

Having a common dream and working for it, making it possible (changing the society).

(Musician-teacher, parenthesis original)

At the time of writing, the women who attended the Encouraging girls'participation in music in Nepal workshop initiated a Facebook conversation of over 40 members, which turned into a closed Facebook group with over 30 members. They held meetings and rehearsals to plan and organize an all-female gig to raise awareness and enhance female participation in music in Nepal. The gig was held in January 2017 with six acts and over 20 performers, including performances of new compositions created specifically for the event. In addition, in November 2016 a group of 25 people met, including head teachers and musician-teachers, for an event they titled 'Strategic Planning for the Future of Music Education in Nepal' that made use of the co-constructed visions as a starting point for future work. This group met again in December 2016 for 'Planning for Action' and carefully planned a series of 5 monthly workshops to be held from February to June 2017. Despite this, attendance continued to drop so significantly that not all of these meetings took place and, as of this writing, a small group of committed and enthusiastic musicianteachers are reconsidering their approach. Their experience highlights the extremely fragile nature of teacher communities.

The original enthusiasm for their meetings may have been attributed to their initiation by a foreign teacher who participated in the workshops and taught at the prestigious international private school where the meetings took place. Because of this, the community could be seen as continuing to be organized in cooperation with a 'foreign expert' and therefore possibly related to feelings of "success in a globalised world" (Appadurai 2006, 172). However, it may be that this foreign teacher has access to resources, in terms of time and financial stability for example, that the local teachers do not necessarily have. Additionally, it was also suggested that the diminishing attendance may have been related to the current lack of collaboration between institutions - a lack of collaboration countered in the vision "To develop unity between the major music institutions in Nepal so that activities become more controlled, efficient."

Thus, for workshops or meetings such as these to survive, it is not enough that they are valued by, for example, the musician-teachers. More importantly, they need to be valued and supported by the educational institutions "as vital sources of knowledge and action" (Cochran-Smith and Lytle 2009, 154), so that participating 
in and organizing workshops is not merely something left to the responsibility of teachers and relegated to their limited free time. Rather, institutions should consider what is essential to "create and sustain the conditions for critical inquiry communities within and across settings," for example by making "inviolable the necessary time for substantive collaboration" (Cochran-Smith and Lytle 2009, 154), perhaps by including such meetings as part of the paid work of a teacher. Such actions would open the right to research to a wider community. Indeed, Schmidt and Robbins argue that "success will be more likely if the work of such communities is systematically structured as part of a school- or district-wide educational mission" (2011, 99; see also Cochran-Smith and Lytle 2009).

\section{Intercultural Learnings}

The overarching research question of this chapter sought to consider how the process of co-constructing visions might engage teachers as inquirers in a majority world context, by reflecting upon the 16 Appreciative Inquiry workshops I facilitated with Nepali musician-teachers during an 11-week period. This reflection suggests that as Nepal works to develop its first music teacher education program, a program that needs to educate interculturally competent teachers capable of guiding teaching and learning for students from 126 caste/ethnic groups in 77 national districts in a rapidly changing and globalizing society, decision makers now need to envision the kind of music teacher education program they wish to develop. Do they merely wish to provide teachers with "vocational credentials" (Appadurai 2006, 175), or do they wish to nurture music teachers' capacities "to make independent inquiries about their own lives and worlds" (Appadurai 2006, 173) and thus the teaching and learning taking place in their communities in the face of increasing diversity and an uncertain future? In other words, teachers who have the capacity to imagine, aspire, inquire and take action, and who adopt "inquiry as stance" (Cochran-Smith and Lylte 2009).

The process of co-constructing visions presented in this chapter is one example of potential professional development through engaging in group inquiry. Although some musician-teachers originally participated in the workshops because of the certificate, participating led, for some at least, to an appreciation for both learning from and with each other, and for the already existing knowledge and expertise within their community. At the same time, it fueled a desire to know more and to take action. As can be seen in the co-constructed visions, the process was also "a valuable mode of critique of the inequities in schools and society and of knowledge hierarchies, which have implications within as well as beyond the local context" (Cochran-Smith and Lytle 2009, ix; see also Treacy et al. in press). Recalling Appadurai (2006), however, for other musician-teachers, participation in the workshops may have been the 'cost' of gaining some kind of vocational credential to potentially increase their employability in a country where the current availability of professional development for musician-teachers is extremely limited. 
Reflecting on facilitating this process also highlights my own learning through this, my first experience using AI. My readings of the literature on teachers' visions (see e.g. Hammerness 2004, 2015) suggested that visions are something that teachers have and just need to be asked about, while my readings of the AI literature suggested that images of an ideal future naturally emerge out of the positive examples shared in the Discovery phase. My experience in Kathmandu, however, was characterized by an ongoing search for different angles from which to approach the Dreaming or envisioning, because it turned out to be a rather challenging process. This strongly resonates with Appadurai when he identifies the imagination as "a form of work" $(2006,31)$ and states that "the capacity to aspire, like any complex cultural capacity, thrives and survives on practice, repetition, exploration, conjecture, and refutation" $(2004,69)$. Thus, these workshops were sites for practicing navigating the capacity to aspire with other musician-teachers. Still, working with musician-teachers I frequently wondered how the workshops, the resulting visions, and our overall experiences may have been different if, rather than spoken discussions, we had used music as our primary tool for navigating the capacity to aspire.

Thus, my biggest intercultural learning did not come from the co-constructed visions and their related discussions. Rather, it came from the challenges of the process itself, highlighting the need for intercultural music teacher educators to remain reflexive and flexible. My work required an ongoing willingness to be open to redesigning my plans and finding alternatives, to try again, and again (and again) when needed, and to acknowledge and embrace the ever present and often uncomfortable or unsettling uncertainties of the process, for both participants and facilitators. Throughout, I needed to allow myself to be guided by ongoing dialogue, especially focused on listening, with my co-facilitator and the musician-teachers. This dialogue, whether in person or online, spoken or written, continues to serve an important role in our ongoing reflection and interpretation.

Acknowledgements This publication has been undertaken as part of the project Global Visions through Mobilizing Networks: Co-developing Intercultural Music Teacher Education in Nepal, Finland, and Israel (2015-2020, https://sites.uniarts.fi/web/globalvisions) funded by the Academy of Finland (project no. 286162).

The author would like to thank her co-facilitator Prem Gurung, the musician-teachers who participated in the workshops and shared their perspectives and experiences as part of this research, and the music institutions and private schools who supported the project, dhanyabaad! She would also like to thank the doctoral community at the Sibelius Academy, University of the Arts Helsinki for comments and guidance in refining this text.

\section{References}

Appadurai, A. (1996). Modernity at large: Cultural dimensions of globalization. Minneapolis: University of Minnesota Press.

Appadurai, A. (2000). Grassroots globalization and the research imagination. Public Culture, 12(1), 1-19. https://doi.org/10.1215/08992363-12-1-1.

Appadurai, A. (2004). The capacity to aspire: Culture and the terms of recognition. In V. Rao \& M. Walton (Eds.), Culture and public action (pp. 59-84). Stanford: Stanford University Press. 
Appadurai, A. (2006). The right to research. Globalisation, Societies and Education, 4(2), $167-$ 177. https://doi.org/10.1080/14767720600750696.

Bates, V. C. (2011). Preparing rural music teachers: Reflecting on "shared visions". Journal of Music Teacher Education, 20(2), 89-98. https://doi.org/10.1177/1057083710377722.

Burnard, P. (2013). Introduction. In E. Georgii-Hemming, P. Burnard, \& S.-E. Holgersen (Eds.), Professional knowledge in music teacher education (pp. 189-201). Surrey: Ashgate.

Cochran-Smith, M., \& Lytle, S. L. (2009). Inquiry as stance: Practitioner research for the next generation. New York: Teachers College Press.

Conkling, S. W. (2015). Utopian thinking, compliance, and visions of wonderful transformation. In S. W. Conkling (Ed.), Envisioning music teacher education (pp. 181-194). Lanham: Rowman \& Littlefield Education.

Cooperrider, D. L., \& Whitney, D. (2001). A positive revolution in change: Appreciative inquiry. Public Administration and Public Policy, 87, 611-630.

Cooperrider, D. L., Whitney, D., \& Stavros, J. M. (2005). Appreciative inquiry handbook: For leaders of change (2nd ed.). Brunswick: Crown Custom Pub.

Darling-Hammond, L. (2006). Powerful teacher education: Lessons from exemplary programs. San Francisco: Jossey-Bass.

Dasen, P. R., \& Akkari, A. (2008). Introduction: Ethnocentrism in education and how to overcome it. In P. R. Dasen \& A. Akkari (Eds.), Educational theories and practices from the majority world (pp. 7-23). New Delhi: Sage.

Ferm Thorgersen, C., Johansen, G., \& Juntunen, M.-L. (2016). Music teacher educators' visions of music teacher preparation in Finland, Norway and Sweden. International Journal of Music Education, 34(1), 49-63. https://doi.org/10.1177/0255761415584300.

Gergen, K. J. (1978). Toward generative theory. Journal of Personality and Social Psychology, 36(11), 1344-1360.

Gergen, K. J. (2009). An invitation to social construction (2nd ed.). Thousand Oaks: Sage.

Government of Nepal. (2012). National population and housing census 2011 (National report) (Vol. 1). Kathmandu: National Planning Commission Secretariat Central Bureau of Statistics. [Online] http://unstats.un.org/unsd/demographic/sources/census/wphc/Nepal/Nepal-Census2011-Vol1.pdf. Accessed 15 Jan 2018.

Hammerness, K. (2004). Teaching with vision: How one teacher negotiates the tension between high ideals and standardized testing. Teacher Education Quarterly., Fall, 31, 33-43.

Hammerness, K. (2013). Examining features of teacher education in Norway. Scandinavian Journal of Educational Research, 57(4), 400-419. https://doi.org/10.1080/00313831.2012.6 56285 .

Hammerness, K. (2015). Visions of good teaching in teacher education. In S. W. Conkling (Ed.), Envisioning music teacher education (pp. 1-20). Lanham: Rowman \& Littlefield Education.

Holgersen, S.-E., \& Burnard, P. (2013). Different types of knowledges forming professionalism: A vision of post-millennial music teacher education. In E. Georgii-Hemming, P. Burnard, \& S.-E. Holgersen (Eds.), Professional knowledge in music teacher education (pp. 189-201). Surrey: Ashgate.

Imagine Nepal (n.d.). About us. [Online] http://www.imaginenepal.org.np/index.php/about-us. Accessed 17 Feb 2017.

Jackson, A. Y., \& Mazzei, L. A. (2012). Thinking with theory in qualitative research: Viewing data across multiple perspectives. London: Routledge.

Juntunen, M.-L. (2014). Teacher educators' visions of pedagogical training within instrumental higher music education. A case in Finland. British Journal of Music Education, 31(2), 157 177. https://doi.org/10.1017/s0265051714000102.

Klette, K., \& Hammerness, K. (2016). Conceptual framework for analyzing qualities in teacher education: Looking at features of teacher education from an international perspective. Acta Didactica Norge, 10(26), 26-52.

Kuntz, A. M. (2015). The responsible methodologist: Inquiry, truth-telling, and social justice. London: Routledge.

Lassiter, L. E. (2005). The Chicago guide to collaborative ethnography. Chicago: The University of Chicago Press. 
Liamputtong, P. (2010). Performing qualitative cross-cultural research. Cambridge, UK: Cambridge University Press.

Messerschmidt, D. (2008). Evaluating appreciative inquiry as an organizational transformation tool: An assessment from Nepal. Human Organization, 67(4), 454-468. https://doi. org/10.17730/humo.67.4.xp341p168m141641.

Nepal Appreciative Inquiry National Network (NAINN) (n.d.). Six years' 4 D planning 2005 Sept. - 2010 Oct. [Online] https://appreciativeinquiry.case.edu/uploads/NAINN\%204D\%20 PLAN.doc. Accessed 17 Feb 2017.

Odell, M. J., \& Mohr, B. J. (2008). The power of a positive lens in peace building and development. In M. Avital, R. J. Boland, \& D. L. Cooperrider (Eds.), Designing information and organizations with a positive lens (pp. 307-327). Oxford: JAI Press.

Patel, L. (2014). Counting coloniality in educational research: From ownership to answerability. Educational Studies, 50(4), 357-377.

Rancière, J. (1991). The ignorant schoolmaster: Five lessons in intellectual emancipation. Stanford: Stanford University Press.

Rancière, J. (2010). On ignorant schoolmasters. In C. Bingham, G. Biesta, \& J. Rancière (Eds.), Jacques Rancière: Education, truth, emancipation (pp. 1-16). New York: Continuum.

Schmidt, P., \& Robbins, J. (2011). Looking backwards to reach forward: A strategic architecture for professional development in music education. Arts Education Policy Review, 112, 95-103. https://doi.org/10.1080/10632913.2011.546702.

Sindberg, L. (2011). Alone all together- the conundrum of music teacher isolation and connectedness. Bulletin of the Council for Research in Music Education, 189, 7-22. https://doi. org/10.5406/bulcouresmusedu.189.0007.

Talbot, B. C., \& Mantie, R. (2015). Visions and the legitimate order: Theorizing today to imagine tomorrow. In S. W. Conkling (Ed.), Envisioning music teacher education (pp. 155-180). Lanham: Rowman \& Littlefield Education.

Treacy, D. S. (2019). "Because I'm a girl": Troubling shared visions for music education. Research Studies in Music Education. Advance online publication. https://doi.org/10.1177/13211 03X19845145.

Treacy, D. S., Thapa S., \& Neupane S. K. (in press). "Where the social stigma has been overcome": The politics of professional legitimation in Nepali music education. In A. A. Kallio, S. Karlsen, K. Marsh, E. Saether, H. Westerlund (Eds.), The politics of diversity in music education.

Watkins, J. M., Mohr, B. J., \& Kelly, R. (2011). Appreciative inquiry: Change at the speed of imagination (2nd ed.). San Francisco: Pfeiffer/Wiley.

Open Access This chapter is licensed under the terms of the Creative Commons Attribution 4.0 International License (http://creativecommons.org/licenses/by/4.0/), which permits use, sharing, adaptation, distribution and reproduction in any medium or format, as long as you give appropriate credit to the original author(s) and the source, provide a link to the Creative Commons licence and indicate if changes were made.

The images or other third party material in this chapter are included in the chapter's Creative Commons licence, unless indicated otherwise in a credit line to the material. If material is not included in the chapter's Creative Commons licence and your intended use is not permitted by statutory regulation or exceeds the permitted use, you will need to obtain permission directly from the copyright holder.

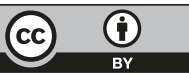

